\title{
Just because they say it is sustainable development, it does not mean that it is: Sustainable development as a master-signifier in Swiss urban and regional planning
}

\author{
Constance Carr \\ Department of Geography and Spatial Planning, University of Luxembourg \\ constance.carr@uni.lu
}

\begin{abstract}
With stunning green landscapes, exemplary public transport, and picturesque walkable cities, Switzerland often occupies the public imaginary of a place that has tackled sustainable development. This research, however, looks under the hood and finds that this development path supports not only modes of capital accumulation, but also certain less sustainable patterns of development and governance. This paper examines this apparent paradox by looking at the role of sustainable development as a master-signifier in Swiss urban development processes. Empirical observations were made in the Glatt Valley of Switzerland, where governing officials of small municipalities are confronted with coordinating urban development under growth pressure within cantonal and federal policy frameworks that claim sustainable development. It can be seen that sustainable development is an empty master-signifier that policy makers engage to justify the quilting of a certain hegemonic discourses of power that reflect in further uneven urban development. By reproducing business as usual market-led urban growth, fragmentation is maintained as are social spatial disparities are entrenched.
\end{abstract}

Keywords: sustainable development, urbanization, discourse, Switzerland, mastersignifier

\section{Introduction}

With stunning green landscapes, exemplary public transport, and picturesque walkable cities, Switzerland often occupies the lay imaginary of a place that has tackled sustainable development. This research, however, looks under the hood and finds that this development path supports not only modes of capital accumulation, but also the respective less sustainable patterns of societal organization. This paper examines this apparent paradox by looking at the role of sustainable development as a master-signifier in Swiss urban development processes. This paper exposes how working through the aims of sustainable development is a multi-faceted, context-specific problem, involving networks of actors that must confront local challenges and simultaneously grapple with the multiple meanings and said objectives of sustainable development. This process is far from straight forward, and, as this paper shows, further uneven urban development is the consequence.

This finding is significant because years of research shows that sustainable development is a powerful concept across North American and European fields of urban and regional planning policy (Carr 2014, 2015, 2018; Carr and Affolderbach, 2014; Carr et al., 2015; Carr et al, 2015; Carr et al. 2018; Carr and Hesse, 2020a/b; Hesse and Carr, 2013, 2020; Krueger et al., 2018) and many cities and countries across the continent are still positioned as post-Rio champions of urban sustainable development (Beatley, 2012; Bulkeley et al., 2018; Shaker, 2015) despite the ongoing social spatial disparities and discontents that have been unfolding, and indeed worsening, over the last decade (Hudson, 2017). This incongruous relationship is already grounds for an inspection of sustainable development as a normative orientation in urban development, and more so given that the need to address climate change is more acute than ever and city development can play a pivotal role in this process (Chen, 2015; Rydin 2010).

At the same time, however, others have also observed the strange relationship between sustainable development policy and the reality of urban conditions: Angelo and Wachsmuth (2015) criticized the 'methodological cityism' that plagues sustainability orientations in urban development; Elgert $(2016 ; 2018)$ and Elgert and Krueger (2012) problematized the epistemologies of metrics and indicators of sustainable 
development that overlook underlying contextual contradictions in urban transformation; Mössner (2013) found socio-political limits of green cities, daring to critique the iconic green city of Freiburg im Breisgau; and, not few have highlighted the problems with market-led urban sustainability (Bunce 2018; Desfor and Keil, 2004; While et al., 2004; Raco, 2005; Krueger and Gibbs, 2007; Krueger et al., 2018; Moore and Bunce, 2009; Hall and Stern, 2014). These criticisms underscore that the 'sustainable development paradox' (Krueger and Gibbs, 2007) is far from resolved, and that sustainable cities cannot be produced by simply finding a 'final state of blue-printed harmony' (Faludi, 1970: 3) reflecting the right balance of the right problems in the right ways with the right instruments. Sustainable development is difficult, full of contradictions, even wicked, "meaning that the problem's boundaries are ill-defined, it concerns multiple actors with conflicting and overlapping interests [and] every attempt to tackle the problem deconstructs and reconstructs problems dimension," (Frantzeskaki et al., 2014). Urban development in Switzerland is not exempted from these critiques. This paper thus joins this chorus and addresses sustainable development as a linguistic device - a master-signifier - that serves not to mitigate uneven development across urban space, but to foster it.

Sustainable development has been identified as a linguistic device before. Gressgård (2015) and Davidson (2012) argued that sustainable development worked as a 'fantasmatic narrative' or a fantasy construct in ways that influence discursive spheres along certain agendas. Davidson (2010) and Glasze (2007) looked at sustainable development as an empty master-signifier - meaning simultaneously everything and nothing - that is nevertheless useful in directing discursive processes of policy-making. These studies demonstrate the diversity of different meanings associated with 'sustainable development' and the, "open-ended and multiple nature of urban sustainability transformations," (Bulkeley et al. 2018: 18). This paper adds to this literature by showing not that there are not only discursive effects of sustainable development as a linguistic device, but also social spatial and material ramifications as well that entrench business as usual market-led urban development. As policy-makers use the master-signifier to stitch together sets of problems into hegemonic discourses that have socioeconomic and corporeal spatial consequences in urban space (such as longer commutes for lower-wage labour), urgent socioenvironmental issues are ignored.

Empirical evidence is drawn from studies of planning practices in Switzerland, a nation known for its extensive railway network and compact walkable cities (Rérat and Lees, 2011; Rérat, 2012), that has enjoyed top marks from the Environmental Performance Index (formerly the Environmental Sustainability Index) several times (Yale Center for Environmental Law \& Policy, 2014), and one where the narrative of sustainable Switzerland is repeatedly reproduced in local media. This paper interrogates this narrative, by focussing on the discursive constructions of sustainable urban transformation in a region that overlies the north-eastern districts of the City of Zurich and sprawls along the Glatt River, identified by some as a postsuburban space (Carr and McDonough, 2018). In this area municipal officials are confronted with the messy task of coordinating urban development under growth pressure on the one hand, while keeping within federal cross-sector planning guidelines - that claim to be addressing sustainable development - on the other. Following discourse theory, this paper argues that certain actors assert certain discourses, establish certain forms of truth over others, and suppress alternative understandings or multiple meanings, and that this is further both an exercise in power and a means of controlling spatial urban development. In the Glatt Valley, cantonal and federal government officials quilt hegemonic discourses around sustainable development with agendas of densification and intensification that translate at the municipal level into market-driven sustainability approaches that maintain and cause further spatial mismatches and socioeconomic problems - a manifestation that is a far cry from the image of Switzerland as the promised land of sustainability.

The argument is structured as follows. First, the concept of the master-signifier will be explained as it is understood in discourse theory, followed by a problematizing of sustainable development as one such example. Second, the object of study - urbanization pressure and the formation of the so called Glatt City and the methods of investigation are described. Third, the empirical evidence is presented that verifies how the linguistic device of sustainable development quilts social spatial and material ramifications. Fourth, the paper then returns to the implication of sustainable development as a master-signifier and the implications for the scholarly debates in European urban and regional geography.

\section{Master-signifiers, sustainable development, planning}

To underscore the meaning and functions of master-signifiers, this paper draws from a rich literature in discourse theory. The original conceptualization of signifiers as a linguistic act can be traced back to Saussure who introduced 'the living language' (Saussure, 1959: 2). He (1959: 7) refuted the idea that 
language was simply a sequence of phonic characters, and that language was not merely a reflection of a pre-existing reality (Glasze, 2007: 658). It was not 'merely a channel through which information about underlying mental states and behaviour or facts about the world [were] communicated' (Jorgensen and Phillips, 2002: 9). Rather, language both generated and constituted the social world (Jorgensen and Phillips, 2002: 9). The scientific implication of this was that social reality could be understood by examining language in action. Reality was linguistically constructed (Gunder, 2004: 309), and real objects only had meaning through discursive constructs and communication acts (Jorgensen and Phillips, 2002: 9).

For Saussure, words had two inferences - the signifier and signified (Gunder, 2004). Furthermore, the relationship between the two was arbitrary (Saussure, 1959: 66-70) because no 'natural' connection between them could be determined. 'Signs' were given meaning and, correspondingly, signified subjects were achieved collectively, forming a discursive networked structure of relational language, wherein signifiers had fixed positions (Glasze, 2007: 659). Scholars from a poststructural orientation later critiqued what they viewed as Saussure's 'inert fixation' (Glasze, 2007: 659), conceptualizing language further as relational, temporally fixed, context specific, and fragile in structure (Feindt and Oels, 2005: 164; Glasze, 2007: 659). Glasze (2007: 660) referred to this as 'fragile fixation'. The structure of language, meanings attributed to speech acts, and texts were therefore in continual reconstruction. Social realities were always fragile, temporary and the product of discursive tensions (Glasze, 2007: 660). This was not to say that there is no such thing as reality (such as natural phenomena like gravity or volcanic activity), but that real objects only had meaning through discursive constructs and acts of communication (Jorgensen and Phillips, 2002: 9). As Jorgensen and Phillips (2002: 12) explained, most poststructuralists view language as: 1) not reflecting a pre-existing reality; 2) structured into flexible discourses; 3 ) discursive patterns that are steered by discursive practices; and, 4) contextually grounded and context explains transformations in discursive patterns. Mastersignifiers are language acts and an analysis of them can explain discursive tensions that characterize social realities.

\section{Sustainable development as a master-signifier}

Davidson (2010), Glasze (2007) and Gunder (2004) identified sustainable development as an empty mastersignifier. That is, sustainable development is both an empty-signifier - meaning simultaneously nothing and everything - and a master-signifier, providing direction for action, securing identity, and supported by sets of knowledge, beliefs, and practices. To first elaborate on definitions:

The basic idea of an empty signifier is that political ideologies are built around social meanings that accommodate divergent interests and identities. In order for specific meanings to perform this function, they must be emptied of particular content, thus coming to play a more universal role, and their meaning is defined negatively by what they oppose. [...] Empty signifiers are thus means of representation that enable the building of alliances between different groups and identities by positing an enemy to be opposed and proposing solutions to the problems facing groups. (Griggs and Howarth, 2002: 47).

There is little difference between empty and master-signifiers, except that:

master signifiers designate to us and others who we are and what we believe, from simple adjectives, such as fat or thin, through our gender man or woman to our ideological and cultural identifications, such as those of 'planner', 'affected resident' or 'homeowner', 'academic', 'socialist' or 'conservative' [...] Sharing with others an identification with a master signifier, such as being a planner, funeral director or businessperson, residential homeowner, or elected politician, fosters a sense of group identity and solidarity. [...] To do so, each master signifier must act as an open and also empty signifier to suture often diverse and contradicting narratives of knowledge, practices, and values under one shared identification. (Hillier and Gunder, 2005: 1053).

The master-signifier is empty, but those engaging the linguistic device temporarily suture nodal points and fix meaning (Gunder, 2004), and thereby quilt a sense of identity or set of values and practices. Mastersignifiers are named; that is, they retain nominal status. This naming is a totalizing function by which disassociated or free-floating elements can be quilted; that is to say, temporarily secured and structured (Davidson, 2010). 
Master-signifiers are useful in understanding sustainable development as a speech act, because who gets to quilt, what, and why, and who or what is excluded become central questions. Gunder (2004) and Hillier and Gunder (2005) showed how master-signifiers are useful in understanding the planning profession, arguing that planning professionals not only required master-signifiers to both justify their practices and assuage sincere desires for a better world (Gunder, 2004: 309), but also defended planning-related mastersignifiers as an important part of their profession (Gunder, 2004: 302) As a master-signifier, sustainable development becomes a structuring agent, an organizing discourse, or. an ordering device upon which meaning can be ascribed and understood in specific contexts. The content is arbitrary. In this light, sustainable development is something other than a sustainability process, an end-point or development goal, or a guiding principle like justice or liberty (Holden et al., 2014). It is also more than just a policy in motion or a fuzzy concept, as several scholars have already indicated, where barriers merely need to be broken down or concepts simply clarified (Carr, 2013; McLean and Borén, 2014; Carr et al., 2015). As a mastersignifier, something else about sustainable development is exposed - namely arrangements of power that characterize or drive sustainable development discourses.

The master-signifier of sustainable development enables anyone with the relevant resources to maintain hegemony in discourse, enact an agenda across space, and claim sustainability - and these are questions of power. Affirming Howarth's (2014: 100) interpretation, a master-signifier takes hegemonic form. Feindt and Oels (2005: 163-164) understood that discursive acts indicate power arrangements, where certain forms of truth are established over others through discourse, demarcating arrangements of power (Feindt and Oels, 2005: 164). Glasze (2007) explained this in terms of Gramscian hegemony:

[the] expansion of a discourse into a dominant horizon of social orientation that partially and temporarily fixes the meaning of discursive elements around nodal points [...] there are no determining laws, which divide society into particular groups, rather, groups are constituted in discursive processes [...] The development from discursive struggle to objectivity is realised in hegemonic interventions whereby alternative understandings of the world are suppressed (Glasze, 2007: 661).

For Žižek (2004) it could be used to explain master discourses, whereas masters redouble on subjectpositions at Lacan's quilting point, affirming constellations of authority and the psychoanalytical contradictions therein, such as the 'postrevolutionary new Master who does not want to admit that he is one, but proposes himself as a mere 'servant' of the people' (Žižek, 2004: 388). Clear is, that the grouping around a discursive reference point makes it possible for identities, identity groups, subject positions, or imagined communities to form, however temporarily, forming 'chains of equivalences' that demarcate insiders and outsiders around a specific nodal reference (Glasze, 2007: 662). This temporary fixation of meaning of discursive elements is a hegemonic intervention that establishes certain forms of truth over others, suppresses alternative considerations, and reaffirms differentials in authority. This has ramifications on how normative orientations of sustainable development can be evaluated.

\section{Object and Methods}

This paper underscores that sustainable development is a useful linguistic device (a master-signifier) that causes further spatial and corporeal ramifications in urban transformation. This was one of the results of a research project investigating the discursive practices of sustainable development, planning, and urban transformation in the Glatt Valley (figure 1) - a region that overlaps and lies to the north and northeast of the City of Zurich, and stretching between the Swiss International Airport and Lake Greifen (and some say outwards also to Wintherthur). Because the Glatt Valley is not a specifically defined or bordered region, the number of municipalities that belong to the region is a number that varies according to who one asks; however, Opfikon, Wallisellen, Bassersdorf, Dübendorf, Rumlang, Kloten, Wangen-Brüttisellen, Dietlikon, Schwerzenbach, and Fällanden (figure 1) are often included. The Glatt Valley was chosen as an object of study because it can reveal the different ways that growth pressure can be confronted and dealt with. Its economy is largely driven by the financial and related services industry, and it is a region of high income wealth associated with high land prices. Decision-makers are thus faced with challenges associated with growth pressure, engaging the resources available, and limited to, the existing palate of planning institutions and regulations (see next section for details).

Indeed, Swiss planning systems are often positioned against the backdrop of Switzerland as the poster child of sustainability: the nation boasts an extensive and punctual train and tram network; many cities 
exhibit walkable neighbourhoods and pedestrian zones; bicycle usage is popular and ubiquitous; and in terms of greenspace, Switzerland invokes images of snow-capped Alps surrounded by lush green valleys and meadows. While Switzerland exhibits some of the hallmarks of popular sustainability (greenery, walkabilty, etc.) many parts of the confederation, including the Canton of Zurich, and the Glatt Valley, struggle with local politics of not only xenophobia, but also free-wheeling neo-conservative administration of capital investments. (Diener et al. (2005) addressed the social production of Switzerland, and by applying Lefebvre's concept of the urban mille-feuille.) It is no mistake that Swiss sustainability is complemented by Swiss political economic niche strategies strategically positioned in cross-national and global flows.

Practices of planning in the Glatt Valley can reveal how linguistic acts shape planning policy, subsequent material change, and socio-political inequities. In order to understand of how the master-signifier of sustainable development functions to structure hegemonic discourses and social life, constructivist approaches were undertaken. Discursive practices in media (newspapers, websites, public documents) and in conversations were researched. This demanded an extensive document survey as well as over twenty-five conversational interviews with practitioners in the fields. Topically, media was scanned for discussions on urban planning dilemmas. Government documents were reviewed to understand the planning responses. These included documents from both the Federal Office for Spatial Development (Bundesamt für Raumentwicklung, ARE) - the bureau that oversees and encourages a nationwide coordination of land use development - and the Canton of Zurich. The Office of Spatial Development at the Canton of Zurich also published an impressive list of documents in same time frame. These include the Official Cantonal Spatial Plan (OCSP) (Richtplan), annul reports, various so called 'studies' commissioned by the canton and carried out by governmental offices, planning and development firms. At the municipal level, the availability and kinds of publications was rather heterogeneous, which reflected the variety of administrative structures that exist across the region - some municipalities having planning offices, for example, while others not. In general, available publications under the rubric of 'planning' were usually technical publications about landuse zoning, regulations for infrastructural development, permit procedures, and cadastre maps. Social or political issues that might contextualize them, were also available in the news sections of municipal websites. To augment information that could be derived from the websites of the municipal administrations, local magazines, and newspapers, such as Glattaler Hochparterre or Wohnen, were reviewed.

Against the background of written discourse, interviews with governing officials, planners, architects, urbanists, real estate agents and developers were undertaken. First, key actors and experts in the areas were searched out. These were planners or local scholars who had researched in the area for many years. Exploratory and informal discussions with these enabled an initial understanding of the broad problems and planning approaches. They were also helpful in naming further interview partners. Interviewees were also searched out by taking note of who authored the collected documents, and who the prominent public figures were (such as those repeatedly featured in newspapers, for example). As names were collected, and as interviewees were met, further possible interview partners were identified by snowball effect. In this way a cross-section of interviewees were collected, representing a diversity of viewpoints.

Interviewees were probed for their views on spatial planning problems and dilemmas, and sustainable development. All interviews were transcribed and coded in MAXQDA. This enabled continual re-readings, transversal analyses, and tabular structuring of the conversations. For this paper, passages were extracted that referred to mechanisms of local development, issues of small state governance, problems of existing vertical patterns of government and planning policy, and understandings of sustainable development. In this way, it was possible to: (a) unpack the character, function, and discursive tensions of municipal land use that mismatches with upper level directives; and (b) understand why upper-level master-signifiers of sustainable development do not work.

As a point of clarification, sustainability and sustainable development are used indiscriminately in this article. While there is extensive scholarly discussion already on the refined differences and implications of the two terms (Holden et al., 2014), it was found that interviewees generally did not distinguish them. This was, in part, a result of translation as most interviews were held in German. Still, 'sustainable' (Nachhaltig), 'sustainability' (Nachhaltigkeit), and 'sustainable development' (Nachhaltige Entwicklung) were used interchangeably by the interviewees; hence, the decision to use them interchangeably here as well.

\section{Masterful development, ambiguous sustainability}

Sustainable development has arrived in Switzerland. Every single interviewee had something to say about it. In this section, it is shown that the master-signifier serves several proposes depending on whether it is used by municipal authorities or upper-level (cantonal or federal) authorities. The section is divided into 
three parts. First, the institutional setting of Swiss spatial planning is described because it helps to understand how discursive constructs concerning municipal development in the Glatt Valley are framed by institutional limitations. In the second part, it is shown how local officials and community activists perceive immediate challenges in their municipality and how to address them. So far, these problems are incongruent with the cantonal and federal directives or plans that claim sustainable development, which are shown in the third part.

The institutional setting of urban planning in Switzerland and in the Glatt Valley

Hoelzel (2014) and Koll-Schretzenmayr and Schmid (2003) are very useful resources, introducing readers to the institutional setting of Swiss spatial planning. It is thus only necessary to repeat the salient points here as they relate to land-use policy and urban transformation in the Glatt Valley. These concern the legal framework concerning land-use planning on one hand and the set of non-binding guidelines on the other.

The legal framework of Swiss urban spatial planning is structured in a nested hierarchy, whereas lower level governing institutions are contained within and are responsible to higher ones. In the case of the Glatt Valley, the municipal responds to the regional, which responds to the cantonal, which responds to the federal. In many ways the system represents a prime example of the classical Type I 'Russian Doll' multilevel governance (MLG) structure that have been explained in the seminal works of Hooghe and Marks (2001; 2003). At the federal level, the Spatial Planning Law 1979 (Raumplanungsgesetz, RPG) sets the legal framework for land-use across the country (Swiss Federal Council, 2015), indicating certain rules that must be adhered to by all cantons. At the canton level, the OCSP (Richtplan) is the pertinent legally binding document with respect to spatial planning. This is the document that binds regional plans within their jurisdiction. Revised roughly every ten years (Canton Zurich, 2014), it presents a broad picture of land use development across the canton, addressing issues of settlement, landscape, transportation, waste management, and public infrastructure, while targeting neither particular plots of land nor specific landowners (Kanton Zürich, 2015: 3). There are twelve regional bodies across the Canton of Zurich that, in turn, lay the development trajectory more precisely, defining the structure of settlement areas, usages for particular pieces of land, target-levels of densification, the degree to which a particular area may transform, where productive, recreational and natural areas shall be (Kanton Zürich, 2015: 3). For the Glatt Valley, the relevant body is the Zurich Planning Group Glattal (Züricher Planungsgruppe Glattal, ZPG). With the assistance of the Glatt Regional Spatial Concept (RegioROK Glattal), it develops the legally binding Regional Development Plan (Regionaler Richtplan) together of the representatives from the municipalities in the jurisdiction. These include Bassersdorf, Dietlikon, Kloton, Opfikon, Wallisellen, Rümlang, Dübendorf, Wangen-Brüttisellen, Maur, Greifensee, Fällenden, Schwerzenbach, Volketswil, and Nürensdorf. Within this institutional framework, the municipalities determine the still finer zoning and implementation details, negotiating between developers and landowners. All plans must be approved and ratified (by vote) by constituents registered in the respective jurisdiction, and then approved respective overarching authorities. This vertical back and forth is referred to as the Counter-Current principle (Gegenstromprinzip) and in Swiss discourse is understood to as a guarantee of democratic values through practices of direct democracy.

In addition to the legal framework there are also non-binding guidelines that planning authorities can draw upon. Many are available at the websites of the ARE. While the spatial planning programmes orchestrated by the Federal Office for Spatial Development (Bundesamt für Raumentwicklung, ARE) are informed by the ideas published in Raumkonzept Schweiz (Schweizerischer Bundesrat, KdK, BPUK, SSV, SGV , 2012) and echo the values outlined in the RPG, it has little leeway to dictate how their goals are to be met. Financial instruments are thus used to encourage specific developments. The Agglomeration Programme is one example. If the federal level deems a given project proposal to lay within the objectives of their programmes, it can allocate funds to support it (Koll-Schretzenmayr and Schmid, 2003). So far, the funds have been used for transport infrastructure, among which was the newly completed tram in the Glatt Valley (Schweizerischen Bundesrates, 2014).

The character of municipal development in the Glatt Valley - Small is not always beautiful

While it is imperative not to fall into essentialist categories, "small" may be viewed as a category that frames development challenges in the Glatt Valley. First, it is an agglomeration of numerous municipalities with populations ranging between seven and nineteen thousand. Second, territorial jurisdictions are small, leaving municipal officials with limited land resources and no hinterland. Smallness is relevant because it can expose the relative growth pressure: There has been a population growth change between twelve and forty percent 
over the last twenty years and the area is now a magnet for incoming commuters. While absolute numbers may seen insignificant, the relative pressure exposes constraints on existing resources. In this setting certain set of difficulties are generated with respect to a) flows being cross-border and the needs for inter-municipal co-operation, b) the challenge of ensuring long-term economic stability; c) appropriate administrative capacity, and for (preferably long-term) economic in/stability. These are the immediate challenges that municipal authorities face, that ultimately define the parameters of sustainability. Problems include (Carr and McDonough, 2014): 1) the new/modern versus the old/traditional as formerly rural lifestyles collide with new lifestyles of high rise living; 2) those included (older residents, landowners) versus those so far excluded (immigrants) from political decision-making processes; 3 ) labour versus residents as high-income earners can afford the new luxury apartment units and lower income earners face longer commutes; 4) some municipalities are positioned to benefit more than others. In this context, sustainable development was either perceived as a pragmatic management problem of stability for existing residents or a technical problem about energy reduction and environmental protection really only doable if feasible. Second, it was clear that business development is of high priority, and the role of private development in any sustainability effort is considerable.

While municipal jurisdictions are binding, flows are cross-border. The municipalities of the Glatt Valley lie in an area that receives spill over effects from economic growth centred - historically, at least - in the City of Zurich. In recent years, new construction and infrastructures emerging throughout the region have rendered it difficult to the untrained eye to determine the boundaries between the municipalities (figure 2). Further, 'the agglomeration grows together but not politically' as one developer (Interview, March, 2014) commented. This generates internal and inter-municipal conflicts as well as difficulties in generating common agendas (figure 2). This problem is further exacerbated by varying perceptions with respect to the efficacy of inter-municipal communication and co-operation (figure 3).

Municipalities are confronted with continual economic instability and uncertainty. As municipalities are in charge of maintaining local infrastructure and providing various services, they remain primarily concerned with balancing state budgets. Their ability to do this successfully depends on changes in highlevel tax laws, and the desires of local businesses to remain in the municipality, and their ability to maintain economic growth that they perceive is necessary. In this context, municipalities stress the need to maintain good relations with local businesses, towards the success of maintaining municipal tax revenue (figure 4).

The municipalities in the Glatt Valley are characterized by short social distances and local administrations that oversee and manage local municipal functions tend to be sparsely staffed relative to the amount of jurisdictional responsibilities. Many employees wear two hats, not only administering in several fields of responsibility - including some that they are not trained for - but also sometimes having two jobs. This character of small state government - 'militia government' (Milizsystem) as it is termed in Switzerland - has been already described by Affolderbach and Carr (2016) and is not unique to Swiss municipalities. It is, however, central in understanding the relationship between small state governments and the private sector. It is a situation where everyone knows each other and where some decisions can be made very quickly. A lack of in-house competencies often result in professionals being contracted out (figure 5).

These small municipalities retain a high degree of autonomy over schooling, health services, social services, policing, waste and recycling management, water and sewage infrastructure, tax revenue and distribution, and land use planning, and these must be managed in continual view of unfolding socioeconomic contradictions. Lacking the resources and mechanisms to address problems, municipalities often turn to and co-operate with private stakeholders. Small municipalities and private developers are thus a perfect match. In terms of land-use planning, most municipalities preferred to contract planning work to external professionals, while developers viewed the government as a service provider, existing for the purpose of approving or assisting with projects. In fact, the developers that were interviewed tended to have a certain dislike for larger administrations such as the City of Zurich. Private developers preferred to position themselves as well established in the tightly knit municipal social networks where they can bring local municipal officials in contact with international stakeholders -- contacts maintained though conferences and property market fairs (figure 6). There exists, therefore, a mutually reinforcing relationship between lean government and private market development.

Discussions of sustainable development at the municipal level were bound to jurisdictional issues, such as technicalities such as low energy infrastructures, technical specifications and certifications. A good example of this is the widely promoted 2000-Watt society, Richti Areal, built by Allreal (figure 7). Other discussions were about biodiversity and nature protection. Also not uncommon were more general formulations where the day-to-day praxis involved questions of societal steering and general pragmatism. 
These interviewees defended their work because in addressing local challenges, engaging in direct democracy on a regular basis, and making informed decisions, they viewed their approach as close to sustainable development one could hope to get (figure 8).

\section{The federal and cantonal sustainable development strategies}

Interviewees identified, in particular, three governing directives that were most relevant in binding municipal development: (i) the RPG, and in particular, a recent amendment that froze any extensions of the building perimeter; (ii) the federal Agglomeration Program; and (iii) the OCSP (Richtplan). All three explicitly claimed sustainable development. Together, these ultimately encourage the construction of apartment complexes (built on derelict industrial sites) and transport infrastructure along certain corridors to ease the flow of labour and business, and protect so called natural landscapes. In the Glatt Valley specifically, the building perimeter has scarcely changed in the past twenty years, while land prices have increased between fifty and two-hundred percent.

As mentioned above, the RPG is Switzerland's nationwide spatial planning law that binds the cantons along certain tenants of development that include (Swiss Federal Council 2015): 1) the efficient use of lands, while protecting soils, water, air, and forest; 2) ensuring that settlement structures are built on pre-existing building sites; 3) compact design of new settlements; 4) taking care that enough space is available for economic activity; and 5) securing enough resources for the nation. In May 2014, further amendments were put to law that accommodated the so called Landscapes Initiative (Landschaftsinitiative). Drawing on technical explanations, such as the apparent number of square meters being consumed by construction per second (Landschaftsinitiative 2015a: 3), and so called evidence published in earlier government documents that claimed that development was out of control, proponents of the Landscapes Initiative pushed for a restriction on the further allocation of building plots beyond the existing zoned building perimeters (Canton Zurich, 2014). On March $3^{\text {rd }}$, it was accepted by majority vote across all Swiss cantons with the exception of Wallis, meaning that the law would pass and that the onus was next on the cantons and municipalities, irrespective of individual situations, to implement it. In practice, this translated to compact town planning, smaller building plots, the building of new housing along existing transport conduits, the intensification of existing building lands or previously derelict areas. 'Inward densification' (Verdichtung nach innen) was the motto and sustainability was claimed result (figure 9).

The ARE - the federal office in charge of Swiss-wide spatial development - holds sustainable development in the highest priority:

Switzerland bases its understanding of sustainability on the definition provided by the World Commission on Environment and Development [...] Sustainable development is a tenet to which the Swiss Confederation and the cantons are bound. Article 2 (Object) of the Federal Constitution declares sustainable development to be a national objective, while Article 73 (Sustainability) calls upon the Confederation and the cantons to strive for a balanced relationship between nature and its ability to renew itself, on the one hand, and the demands placed on it by the human race, on the other. To date, the Federal Council has implemented these constitutional obligations by means of sustainable development strategies. (ARE, 2015).

Accordingly, the term figures prominently on the ARE's web-pages and documents. A recent document is the Sustainable Development Strategy 2012-2015 (Strategie Nachhaltige Entwicklung, 2012-2015) (Schweizirscher Bundesrat, 2012). Presented at the United Nation's meeting on Rio+20, it represents the latest statement concerning Switzerland's international commitments, outlining ten key challenges, measures towards sustainable development and methods in monitoring, assessing and promoting local sustainability initiatives. A plethora of further documents expounding on sustainable development are available for download at their website (see ARE, 2009, 2012a, 2012b, 2012c, 2012d, 2013a, 2013b, 2013c, 2013d, 2013e, 2014a, 2014b; Bundesamt für Energie (BFE), 2011, 2014; Bundesamt für Statistik, 2013; Federal Statistical Office, 2008; Lobsiger-Kägi et al., 2014; Richard et al., 2012; Schweizirscher Bundesrat, 2008; Schweizischer Bundesrat et al., 2012).

Linking the sustainable development discourse to spatial strategies of housing and transport, the ARE's Agglomeration Programme (Agglomerationsprogramme) is the most relevant. It aims to integrate town planning, landscape and transport to achieve sustainable development (ARE, 2014a), as one interviewee confirmed: 
Sustainable development is naturally a standard of regional planning [...] It is about environmental protection, landscape, the interleaving of housing and transport and so forth. And these are all aspects that form the basis of integrated regional planning. The whole point of the Agglomeration Programme is that one wants to address the cross-border and institutionally fragmented space using the paradigm of sustainable development. (Interview with Project Coordinator, October, 2012).

The programme functions as a planning instrument that works by awarding financial subsidies to project developers that align infrastructure development according to its directives. So far, the programme has financed over 35 projects in the Glatt Valley alone (ARE, 2015b). Mostly, these concerned tramway projects and up-valuing of train stations. They also included cycle lanes, and upgrading of town centres (ARE, 2015b). The Agglomeration Programme also encouraged the formation of a cross-municipal political group called the Flugahafenregion (formerly known as glow.dasGlattal) (Interview with Researcher, March 2014), a platform for inter-municipal exchange, and one whose primary objective is to attract businesses to the region (Interview with member of Flugahafenregion, April 2014).

While proponents of the programme justified their goals as upholding the values of sustainable development, players in the field were less convinced

The projects are supposed to realize the goals set out in the [ARE's] Agglomeration Programme. At this point, sustainable development looks quite different. What does the housing stock look like and what energy standards to they have? What architectural form and quality do they have? Who processed the individual cases and how? In the end, this sustainable development spatial planning is a very orthodox system in which a schema is illustrated and where they now try to pull through with the gigantic machinery of the Agglomeration Programme. The positive about it is, that at least, they really try to do it - although despite lots of preaching, hardly any region can actually manage it. But at the same time, it is a relatively rigid system of density planning and allocation of economic spaces. This has been known for 30 years. (Interview with Project Coordinator, October 2012).

At the cantonal level, the OCSP is the pertinent legally binding document that 'controls the sustainable spatial development' of the Canton (Kanton Zürich, 2014). Its primary objective is to coordinate town planning and spatial development as to adhere to federal objectives, overseeing that housing and transport infrastructure are built on existing building or previously derelict areas. Again, the motto was Verdichtung nach innen, and that land is held in tight reserve. One planner also confirmed that scarcity of land and maintenance of high land values was in the express interest of the canton (figure 10). Sustainable development is the said objective of all cantonal policies. Again, the term decorates the pages of the agency's website, and a plethora of documents are available that proclaim sustainability as their primary objective (Amt für Raumentwicklung, 2009, 2012, 2013a, 2013b, 2014a, 2014b, 2014c, Amt für Raumordnung und Vermessung, 2001, 2010; Association Internationale des Urbanistes (AIU) and ARE, 2004; Amt für Verkehr, 2014; Verein Metropolitanraum Zürich, 2014).

\section{Sustainable developments masterfully empty}

It is clear that the notion of sustainable development plays an important role in the discursive construction of Swiss urban and regional space. Sustainable development is a master-signifier that government officials can use in order to temporarily suture nodal points and fix meaning around a set of values associated with normative orientations of sustainable development. Further, equipped with the relevant resources - political legitimacy, financing, and authority - officials had the means to exercise their sustainable development strategies as a discourse of power. In the case studies here, sustainable development is indicative of several different agendas and associated arrangements of power, multiple sustainabilities, and corporeal spatial consequences.

In analysing sustainable development as a speech act, those who have the means to endorse this normative orientation can be exposed, as well as who or what will be marginalized or excluded. As a mastersignifier, sustainable development is a structuring agent to organize discourse, where 'chains of equivalences' delineated insiders and outsiders around a nodal reference (Glasze, 2007: 662) quilting together a hegemonic discourse. In this way, the master-signifier of sustainable development functions as a tool of power. It is thus a useful means of identifying who wins and who loses from sustainability initiatives.

The immediate challenges that municipal administrators confront stand in contrast to cantonal and federal directives of sustainable development that are vaguely formulated and buttressed with legal and financial 
means to endorse them. The municipalities of the Glatt Valley are concerned with daily and long-term management of the resident population, public services and infrastructure, and state finances, as well as addressing ever unfolding respective dilemmas and problems. The tools that they have to work with are framed by small municipal administrations, unstructured and unpredictable patterns of inter-municipal communication, and the need to attract and take care of private sector industries, the real estate industry in particular. Municipal policies and agendas are geared and restricted to their respective jurisdictions following the logics of the nested governing hierarchies that characterizes Swiss government. Sustainable development in this context refers only to processes inside this territory, not necessarily responding to issues of wider coherence. Addressing the concerns of wider electorates, cantonal and federal levels respond to different logics. Cantonal and federal levels of government aggregated certain aspects of spatial problems (densification, landscape protection, economic development, and transport infrastructure), that overlooked municipal needs to address socioeconomic equality, political inclusion, reliable inter-municipal cooperation. Instead, building perimeters are restricted, and subsidies are provided for particular flavours of development. Ultimately, densification, intensification, and integration were said to deliver the desired transformation. This endorsed compact high rise developments, reuse of derelict industrial sites, protection of greenery, and energy consumption, without comment to how or who would deliver this and who would profit the most.

In the Glatt Valley, sustainable development policies were directed at very particular electorates situated within respective jurisdictions, indicating different agenda and arrangements of power. At the cantonal and federal level, batted in were the disparate views and needs of electorates situated across the variety of Swiss jurisdictions. The Agglomeration Programme, in particular, seemed more a means of wealth distribution, batting in those in need of financial subsidies. At the municipal level, batted in were the municipal electorates and sustainable development functioned to justify certain decisions and policy results, making them palatable to electorates. Also batted in were municipal projects developed in tandem with real estate companies that typically materialize high-end medium-rise apartment blocks along the tenants of density planning, and low energy building.

Conceptually, batting in can be viewed in different ways. Some have observed that the emptiness of sustainable development can be a valuable tool enabling communication across populations that do not share the same perspective - a sort of batting-in on the long-arm quilt (to borrow further terms from needlework). Evan and Jones (2008: 1417) referred to this as an attempt to generate a space for deliberation on a shared territory. The emptiness may also be a means to green-washing policies. Swyngedouw $(2007,20)$ reminds that no one wants to oppose sustainability: even George Bush Jr and the catholic pope are in favour of it. The emptiness may also be a means to engage ritual practices that reinvoke politics of reattachment (Gressgård, 2015). Davidson (2010, 2012) showed how notions such as the "sustainable city" operate as fantasy constructs, and how the master-signifier of sustainable development operates to redirect discourse. This paper also showed how policy discourses are redirected. However, it also demonstrates how the mastersignifier also endorses informal arrangements of land use regulation. Affolderbach and Carr (2016) referred to these as blended scales of governance, and in this case, batted in are development agendas of market-led sustainability, which has already sparked much criticism elsewhere in other contexts (While, Jonas and Gibbs, 2004; Raco, 2005; Krueger and Gibbs, 2007; Moore and Bunce, 2009; Hall and Stern, 2014). Tracing sustainable development as a master-signifier confirms these observations, adding to discourse theory that the redirected policies and informal development agendas also have material corporeal consequences. There is also a spatiality to the hegemonic discourse.

Looking at what is not on the quilt is equally important. At all levels of Swiss government, not on the quilt are those voices beyond the respective jurisdictions, and of other sustainabilities. At the municipal level, curious is that the City of Zurich is quilted out, and other scholars have already commented that municipalities in the Glatt Valley want to generate an economic force that rivals its big brother neighbour (Koll-Schretzenmayr and Schmid, 2003). Also off the quilt are those doing the work, trying to implement sustainable development policy directives but encounter stumbling blocks nonetheless, as was hinted at in the interview with the Project Coordinator (October 12, 2014): At the moment of implementation, "sustainable development looks different". Quilted out are those beyond the, "rigid system of density planning and allocation of economic spaces" (ibid.). These include the myriad of social spatial problems that were not addressed, or in fact made worse. There are three points to be made here. First, tracing the master-signifier has revealed the real and existing multiple natures and multiple sustainabilities, confirming previous work by Krueger and Gibbs (2007). Some of the interviewees, at least, genuinely believe they are pursuing it, and there are several policy approaches evident. Government directives were hegemonic, those 
outside not so. Second, this research has shown that sustainable development does not solve the conflicts related to economic development versus socio-ecological sustainability. There is no promise of rigorous engagement with social inequalities, stratifications, or polarizations. Further fragmentation and new challenges are the result. Third, sustainable development functioned to conceal specific agendas and goals. In this regard, the emptiness of the sustainable development master-signifier may be exactly what proponents of the concept appreciate. In the case of the Glatt Valley, sustainable development processes were market-led. Intensification and densification are driven by the real estate industry, this can be masked as governmental and representative of resident electorates, and this has social spatial consequences.

This research thus supports the existing palate of literature that critically examines sustainable development and urban transformation. Tracing the sustainable development master-signifier shows that so far, efforts are patchwork at best. The outstanding question, then, is: What does it mean for sustainable development, in general, if Switzerland continues to rank high on the charts for its sustainability endeavours, but retains and furthers so many (often hidden) deficiencies?

\section{Figures}

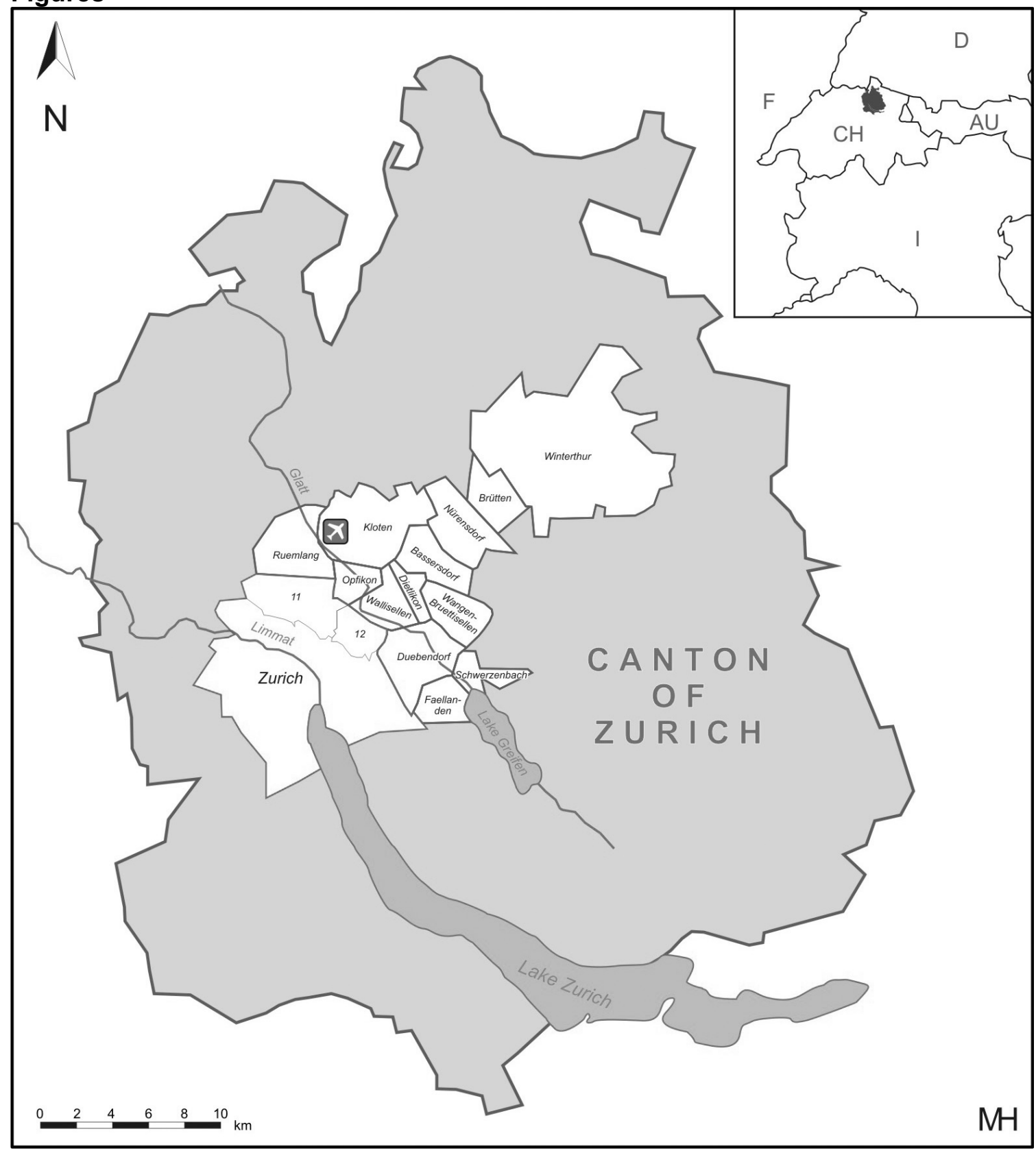

Figure 1 - The Glatt Valley (by Malte Helfer, University of Luxembourg). 
Yes, one can hardly notice the borders between the municipalities. They have grown together. I believe, however, that many in the community are not yet ready for that. (President of municipal administration, March 2014)

If one crosses from here into the neighbouring town, one doesn't notice that one has crossed a border because the border is seamless. (Party representative, March 2014)

In our area there are already seven very large shopping centres [around us...] We cannot now just put in our own industry or shopping mile. That doesn't work. These places have already generated massive traffic and when there is a traffic jam, the drivers search out other routes in neighbouring towns. That means, that we carry the problems. That, of course, leads to conflicts between the municipalities. Some accused us of having enough land to build traffic infrastructure, to which we said, 'Hey, it has come so far that we have now have to give away land to solve your problems.' (Party representative, March 2014)

How we are going to get the municipalities to establish cooperative projects with a common agenda? [...] This is for me central. How can an area transform that is based on a specific pattern of private property and where people actively strive against change?" (Regional planner, June 2014)

Every municipality works for themselves, and decides for themselves how much they want to invest into something. Then, it is hard to coordinate common activities. (Former municipal environmental commissioner, May 2014)

How can one motivate older residents on the hillside, who don't have anything to gain directly, to invest in new developments in the valley for people with whom they have no relationship? They say, 'Those are newcomers. So why do they get everything new? Why do they get a school? Why doesn't the tram run past the city offices where we could get on? Why is our Municipal Officer always down there, and not up here with us?' And so, people start getting jealous. [...]. And I think, the newcomers don't really build relationships to our municipality here, simply because they have an entirely different orientation - to the City of Zurich itself. (Director for municipal infrastructure development, March 2014)

Figure 2 - Interviewees' perceptions of coordination of cross-border flows. 
Astoundingly, there is little exchange between the Glatt municipalities. [...] There is also no obligation. And we, for example, are so preoccupied with ourselves, with our own central places, or neighbourhoods. (Director for Municipal Infrastructure Development, March 2014)

For inter-municipal planning, there is the glow.dasGlattal. They have begun to think about how to organize economic development collectively and attract business (Architect, March 2014)

Wallisellen-Opfikon and Wallisellen-Dübendorf have very amicable exchanges. (Researcher March 2014)

The City of Opfikon and the City of Zurich have a pretty good relationship. (Community Organizer, March 2014)

We have a left City of Zurich and the surroundings municipalities that are right-wing conservative. That is the problem [with current trends in inter-municipal co-operation]. Some don't even have so much as a social democrat in their administrations. (Cantonal Planner, April 2014)

One cannot think only within the municipal borders. So, we - our association - made contacts to the City of Zurich and exchanged some ideas. Then, we got the idea that we need to think a bit bigger, and so the idea of 'Neighbourhood without Borders' came up. The border is right there [points to the other side of the street] So, one has to think across borders. (Community Organizer, March 2014)

Glow is actually a network of municipalities so that they can work together. There is no legal structure to it. It is simply an association, and I like that it is voluntary. [...] But it was founded in order to get the Glatt tram going. (Director of municipal administration, April 2014)

At the moment, we have a very particulate approach. This municipal autonomy is very strong. So, municipalities try to cut as much of the cake for themselves as they can, and there is little readiness to co-operate. (Regional Planner, June 2014)

Inter-municipal co-operation is hard enough with the small municipalities with their small administrations. If we then tried to involve Zurich, it would get much harder. (Former municipal environmental commissioner, May 2014)

Figure 3 - Interviewees' perceptions of inter-municipal co-operation. 
It is difficult to predict how long a business will stay in our municipality. That often depends on higher-level laws, tax politics, or cheaper labour elsewhere. [...] Ok, in ten years: They will still be here. But after that? It is hard to say. It is, therefore, necessary to foster relations between the municipality and the businesses themselves. (President of municipal administration, March 2014)

When a new company comes to our region, then I invite the CEO to a lunch with the president of the community. [...] And so, in this way, the CEO knows the highest man in the community - the president. They have lunch together and at the end he gives him his phone number so he can call if he has questions. [...] This close relationship is very important. All the CEOs are very happy.

(Flughafenregion Representative, April 2014)

It is often so that the municipalities are as healthy or unhealthy as their local industries. And we have received quite a bit of money - not only from taxes but on property taxes. You see, when there is a large enterprise like a shopping centre or cinema, then they are magnets. Everyone wants to go there because everyone wants to get a piece of the cake. And with the demand increases, so do the prices of the property. We earn from that. (Director of municipal administration, June 2014)

If a company decides they want to leave or enlarge, then we have to find a way to come out with less land or less money. We had this 10 years ago. A company wanted to expand and we had to give them the land that our tennis courts were on and think of a different solution to that. (Party Representative, March 2014)

If the municipality has a budget of 50 million per year, and then suddenly new responsibilities arise and they suddenly need 55 million, and if the companies suddenly pays less tax because of a tax ruling at high levels of government, and the municipality suddenly has only 45 million, that means that the municipality has to raise the taxes on the residents or they have to reduce the expenditures. Tax revenues can fluctuate quite a lot. (Community Organizer, March 2014)

We have designated economic zones. Companies are settled there, but we notice that this region is perhaps not well suited for them because land value is always increasing and one can earn more money by selling the land and raising apartment complexes. With the profit one could then use other, cheaper, larger plots of land - green space. Certain laws, however, prevent that these days. So many businesses consider clearing their location to build housing, and moving their industry elsewhere in Switzerland or abroad. (Director of municipal administration, June 2014)

With regards to land use planning, we work with a 15 year horizon. (Director of municipal administration, June 2014)

The glow communities said, 'Okay, we have to do something to promote the region and to attract new companies. (Flughafenregion Representative, April 2014)

Growth.... That is a balancing act. [...] The municipalities wish for growth. That is, in fact, necessary. Standstill is never good. (President of municipal administration, March 2014)

Following the canton's planning objectives, all further growth will occur along the axes of major transport conduits. All other municipalities not sitting along these routes will stay as they are without growth. That is a problem because to survive as a small municipality, you need new people. With only old people, stores close. [...] Soon we will not have any more children for the schools. A municipality without a school? Families won't move here. It's a downward spiral. (Director of municipal administration, June 2014)

Figure 4 - Interviewees' perceptions of uncertainty. 
We have a high degree of municipal autonomy in Switzerland. We take care of policing, building permits, health care, schools as well. I am president here, and I overview city planning, marketing and communication, social services department, the tax and revenue office. (Director of municipal administration, April 2014).

The city governments are run on the 'militia government' [Milizsystem]. That means, they are all amateurs: They go to their jobs during the day, and evenings they do politics. And, it is not always easy to have the necessary professional understanding. I am not a planner - good, I have done some learning - but one is naturally dependent on external qualified workers - sociologists, planners, real estate developers, marketers, sometimes even from other countries. (Director for Municipal Infrastructure Development, March 2014)

We saw that the municipalities were getting more and more responsibilities, and some municipalities are quickly at their limit - professionally. Not every municipality has the privilege to hire an environmental commissioner and talk about environmental issues. They simply lack the know-how. But somehow they have to take care of it. And then, it gets somewhat unprofessional, when the building commissioner addresses sustainability issues what doesn't necessarily interest them. (Former municipal environmental commissioner, May 2014)

I represent all of the local property owners, and I am the press relations officer - all in one person. (Developer, March 2014)

I am active in the association and in the municipality. There, I know the whole administration and all the representatives. I just need to pick up the phone if I need something, and it's done. In Zurich it is much harder and takes much longer. (Community Organizer, March 2014)

Wallisellen, Opfikon, Dübendorf - they all have independent municipal administrations, and that has advantages, whereby decisions can be made very fast, simply because they are smaller. If you want to see the president of our city council, you can call and see her at 11 am today. If you want to speak to the president of Zurich's city council, then you will wait until October. If a local company wants approval for a new advertising campaign, then they will get it within the week. In Zurich, they will wait at least a year. (Director of municipal administration, April 2014)

Figure 5 - Interviewees' perceptions of small municipality administration and political representation. 
Do we have a city planner? No, we buy them. We have a secretary for building. He is responsible for planning concerns. As soon as there are more complex problems, we 'rent' the people we need. (Director of municipal administration, June 2014)

Government doesn't have a lot of power. The government is a servant, service provider. [...] Private property is held in the highest esteem [...] In Switzerland, we have a lot of devotion to the market [Marktgläubigkeit]. (Developer, March 2014)

Last week, I was in Cannes for Europe's largest property market fair and exhibition. There was a small (ca. $200 \mathrm{~m} 2$ ). Swiss stand and the whole Swiss property market world meets there. That is maybe 150 people. So, the elite of the Swiss property market world consists of about 100 people, and I belong to that. I know all the important people. [...] the head Credit Suisse Real of Estate, which is one of the largest Swiss contractors, for example. [...] and he represents a fund group. And so, one gets to know all these people. (Developer, March 2014)

Before a plan is signed, one has to study the market. What is the demand, in fact? Does anyone want a high-rise here? At which price? And if we find that it is likely to work, then we build. Otherwise we would just leave it. So, it depends on the market. Then, one comes in contact with the planning offices, of course. It is naturally urban and regional planners. And they have swarms of plans, and lawyers etc. They know everything and want only quality and town planning etc. But they have never seen a rental contract. They have no idea what it means to sell an apartment. Yes, well this is my favourite topic. I am famous for this, and not loved everywhere for it," (Developer, March 2014)

Now it has come to the point where we [the developers] are overloading the municipal administration with projects. (Developer, March 2014)

Sometimes the municipal officer in charge just comes to my desk, and sometimes I go to his. Uncomplicated, like I said, without lawyers. Actually, we look each other in the eye and say, 'I don't agree' or 'yes, let's do it', and then it gets done. (Developer, March 2014)

If this was the City of Zurich, where there is an office for town planning, an office for engineering, etc., this would have all been planned wrong. I am convinced of that. When I see how they proceed...This here, would not have been possible. (Director for municipal infrastructure development, March 2014)

Municipalities surrounding the City of Zurich are generally right-wing and conservative, meaning they view city planning relatively negatively. [...The idea is that] planning interference should be reduced as much as possible because the market can solve it. (Architect, March 2014)

Figure 6 - The role of developers in the Glatt Valley. 


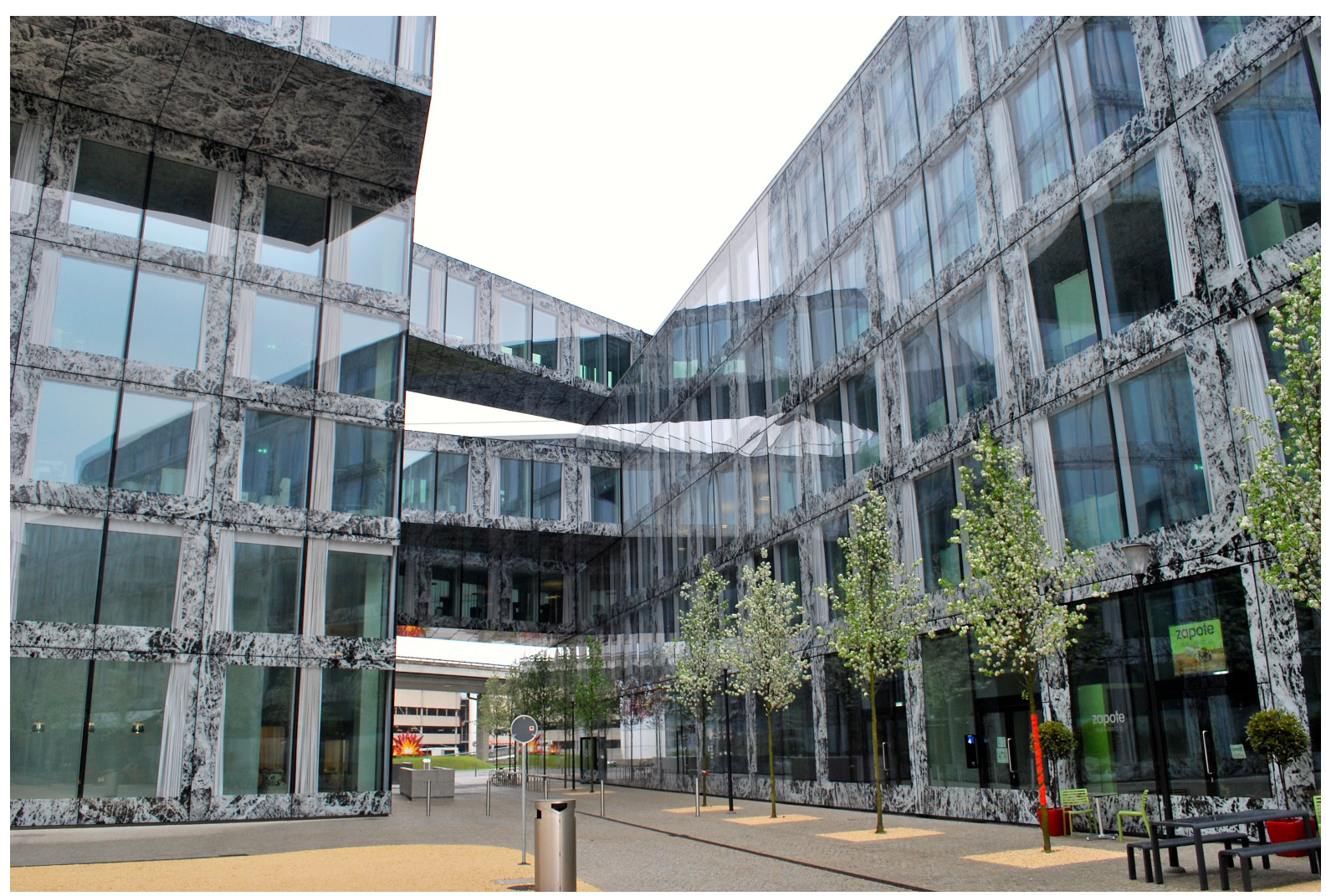

Figure 7 - 2000-Watt society, Richti Areal, built by Allreal (picture by Constance Carr) 
We don't have sustainability checks or indicators or anything. The advantage of a municipality is that we speak to each other, and of course, in our municipal development, we try to make comprehensive and well thought out decisions. So, what does it mean if a school is built? Or, what does it mean when a big development comes? This must all be evaluated. If there is a new school, then it must be clarified how it will be connected to the transport network, and whether or not the municipality afford this. Will there be enough tax payers to cover all the costs? In principle, these arguments are thought through and discussed, and that is sustainable development. (Director of municipal administration, April 2014)

Under sustainable development, I understand that we should be careful with our basic resources, with energy consumption, and that we should build without forgetting future generations. (Director for municipal infrastructure development, March 2014)

What is sustainable? How long must something exist to be sustainable? 10 years? 20 years? 100 years? 200? I believe that we make extra efforts in the municipality to manage things so that they have a use-value for as long as possible, and so that the negative effects are reduced as much as possible. We talk about what we need and what we will need in 10 or 15 years. This includes our infrastructure. You can, for example, lay new and empty pipes at the same time that a street is renewed. That is sustainability. You can in 5, 10, 15, or 20 years pull new cables through without destroying or having to replace the road. That is sustainable development, in my view. Others say that is luxury, because one does not know if one will need the cables in the future. So, sustainability is a difficult topic. But I try to manage operations so that they make sense. And we also try to avoid doing things that are obviously not sustainable. (Director of municipal administration, June 2014)

Sustainability is a permanent task that we have to take on. That simply means that a city of town is never finally built. It must always continue to develop and only then it can stay sustainable.

(Developer, April 2014)

Sustainability? That is my other hat. I always try to bring in issues of nature protection [...] But the Greens are not really on the rise here. Everyone usually speaks of money. People talk of agriculture. But that has little to do with sustainability or ecology. That is a branch of industry. That we still have farmers, and free space is all very nice. But it doesn't have much to do with ecology and protection of biodiversity. At the municipal level, it is low priority that no one really wants to talk about. (Party representative, March 2014)

High priority is the creation of a municipal guideline, and based on that, the building and zoning codes can be amended. We proposed that we follow these with sustainability checks: Is the zoning correct? What density has been achieved? Will it make sense from a town planning perspective? What are the implications for the environment and biodiversity? (Interview with municipal planner, April 2014)

Figure 8 - Interviewees' understanding of sustainable development. 
The Landscapes Initiative attempts again to put a stop to the unsustainable and threatening development in Switzerland. [...] This is to be achieved with a 20-year cap on the building perimeter - That only land can be turned into building land if elsewhere other land is protected. [...]The Landscapes Initiative is open for different means of sustainable spatial development. (Landschaftsinitiative 2015a)

The Landscapes Initiative strives for sustainable town planning, in which ground is efficiently used, landscapes and habitats of animals and plants is protected, and simultaneously offers a higher quality of living to us humans. (Landschaftsinitiative 2015b)

The Landscapes Initiative demands a sustainable town planning that fosters the reduction of motorized individual transport. First, in properly organized, densely populated localities, one should also find employment, shopping, and recreational activities easily reachable by foot or bike. The car or motorcycle could then be avoided, and local business will be strengthened. Second, only properly densely built towns can attach to the transport network. This is not only difficult to achieve by unplanned and sprawled development, it is not profitable. (Landschaftsinitiative 2015c)

Figure 9 - The Landscapes Initiative understanding of sustainability.

The Glatt tram runs through the industrial areas along the peripheries of the Municipalities, in part, because the canton says that urban spaces that already retain a certain level of public transit should be densified, and this should increase the quality of urbanization. (Director for municipal infrastructure development, March 2014).

[The Canton's] philosophy, in fact, goes like this: One should develop where there is an existing provision of public transit. [...] that development is concentrated in certain areas, and this is the purpose of the Official Cantonal Plan (Richtplan). (Municipal city planner, March 2014).

When I see the schedule of canton planners, I am sometimes amazed and think that they don't really have the time to go deeply into the problems. (Regional planner, June 2014)

High land prices. And now I will say something very political: Must it be the goal to keep land cheap? I say, 'no' because if the price sinks then the attractiveness of this economic area increases. We have to keep in control of that. That is how it is at the moment. And that can topple, at which point we would have to think about how to deal with sinking prices. That has national and international dimensions. [...] Of course this has socio-political dimensions, but today one still pays $20 \%$ of their income towards housing, as it was 20 or 30 years ago. If we cheapen land, I would predict that more land would be consumed. And what is the effect of that? [...] If we intervene into the property market, I think that we will produce more problems than solutions. Land must stay a scarce resource. We don't squander land here and it must stay expensive," (Cantonal Planner, April 2014).

Figure 10 - Perceptions of cantonal planning.

\section{Acknowledgements}

Special thanks to the ETH D-ARCH for hosting the author as a Visiting Researcher for the duration of the project. In particular, the author wishes to thank Christian Schmid, Marco Putz, Reto Nebel, Rahel Nüssli, Phillip Klaus, Dirk Lohaus, Med Holden, Evan McDonough, Markus Hesse and Rob Krueger for their continual feedback and support throughout the project.

\section{Funding}

This research was funded by the Fonds National de la Recherche, Luxembourg. 


\section{Declaration of Conflicting Interests}

There were no conflicts of interest at any stage of the research, authorship, and/or publication of this article.

\section{References}

Affolderbach J and Carr C (2016) Blending scales of governance: land-use policies and practices in the small state of Luxembourg. Regional Studies 50(6): 944-955.

Amt für Raumentwicklung (2009) Kanton Zürich Raumplanungsbericht 2009. Available at: $\mathrm{http} / / / \mathrm{www}$. are.zh.ch/internet/baudirektion/are/de/raumplanung/veroeffentlichungen.html (accessed 4 August 2016).

\section{(2012) Verdichtung konkret. Available at:}

http://www.are.zh.ch/internet/baudirektion/are/de/raumplanung/veroeffentlichungen.html (accessed 4 August 2016).

_ (2013a) Raumentwicklung aktuell. Schwerpunkt: Kataster der Öffentlich-rechtlichen

Eigentumbeschränkungen. Available at:

http://www.are.zh.ch/internet/baudirektion/are/de/raumplanung/veroeffentlichungen.html (accessed 4 August 2016). Available at:

(2013b) Raumentwicklung aktuell, Schwerpunkt: Inventare. Available at:

http://www.are.zh.ch/internet/baudirektion/are/de/raumplanung/veroeffentlichungen.html (accessed 4 August 2016). Available at:

_ (2014a) Raumplanungsbericht 2013. Available at:

http://www.are.zh.ch/internet/baudirektion/are/de/raumplanung/veroeffentlichungen.html (accessed 4 August 2016).

_ (2014b) Raumentwicklung aktuell, Schwerpunkt: Projektorientierte Raumplanung. Available at: http://www.are.zh.ch/internet/baudirektion/are/de/raumplanung/veroeffentlichungen.html (accessed 4 August 2016).

__ (2014c) Landschaftsentwicklung Glattraum - Rümlang/Oberglatt. Available at:

http://www.are.zh.ch/internet/baudirektion/are/de/raumplanung/veroeffentlichungen.html (accessed 4 August 2016).

Amt für Raumordnung und Vermessung (2001) "Drieundzwanzigste Plakatausstellung in der StadelhoferPassage Zürich" Available at:

http://www.are.zh.ch/internet/baudirektion/are/de/raumplanung/veroeffentlichungen.html (accessed 4 August 2016).

Amt für Verkehr (2014) Dichte und Verkehr, Beispiele zum Umgang mit Mobilität und Verkehr bei Gebietsentwicklungen in urbanen Räumen. Available at:

http://www.are.zh.ch/internet/baudirektion/are/de/raumplanung/veroeffentlichungen.html (accessed 4 August 2016).

- (2010) Um- und Neubauten im Ortsbild. Available at:

http://www.are.zh.ch/internet/baudirektion/are/de/raumplanung/veroeffentlichungen.html (accessed 4 August 2016).

Angelo H and Wachsmuth D (2015) Urbanizing urban political ecology: a critique of methodological cityism. International Journal of Urban and Regional Research DOI: 10.1111/1468-2427.12105.

Association Internationale des Urbanistes (AIU), ARE, (2004) L'aménagement du territoire en Suisse. Available at: http://www.are.zh.ch/internet/baudirektion/are/de/raumplanung/veroeffentlichungen.html (accessed 4 August 2016).

Beatley, T (2012) Green Cities of Europe: Global Lessons on Green Urbanism. Washington DC: Island Press.

Bulkeley H, Marvin S, Palgan YV, McCormick K, Breitfuss-Loidl M, Mai L, Worth T and Frantzeskaki N. (2018) Urban living laboratories: Conducting the experimental city? European Urban and Regional Studies, https://doi-org.proxy.bnl.lu/10.1177/0969776418787222

Bunce, S. (2018). Sustainability Policy, Planning and Gentrification in Cities. London: Routledge.

Bundesamt für Energie (BFE) (2011) Nachhaltige Quartiere. Bern: Schweizer Eidgenossenschaft. Available at: http://www.nachhaltige-quartiere.ch/de/programm-2011-2013 (accessed 4 August 2016)

Bundesamt für Energie (BFE), Bundesamt für Raumentwicklung (ARE) (2014) Nachhaltige Quartiere in Kürze. Available at: http://www.are.admin.ch/themen/nachhaltig/00262/00533/index.html?lang=de (accessed 4 August 2016). 
Bundesamt für Raumentwicklung (ARE) (2009) Projekte Beurteilen nach den Grundsätzen der Nachhaltigen Entwicklung. Available at:

http://www.are.admin.ch/themen/nachhaltig/00270/02745/index.html?lang=de (accessed 4 August 2016).

- (2012a) Wirtschaftsförderung und Nachhaltige Entwicklung in den Kantonen. Available at: http://www.are.admin.ch/dokumentation/publikationen/00014/00387/index.html?lang=de (accessed 4 August 2016).

_ (2012b) Tourismus und Nachhhaltige Entwicklung - Gute Beispiele und Aktionsmöglichkeiten. Available at: http://www.are.admin.ch/themen/nachhaltig/00264/02601/index.html?lang=de (accessed 4 August 2016).

- (2012c) Nachhhaltige Entwicklung in der Schweiz - Ein Wegweiser. Available at:

http://www.are.admin.ch/dokumentation/00121/00224/index.html?lang=de\&msg-id=12751 (accessed 4 August 2016).

- (2012d) Forschungskonzept Nachhaltige Raumentwicklung und Mobilität 2013-2016. Available at: http://www.are.admin.ch/dokumentation/publikationen/00014/00501/index.html?lang=en (accessed 4 August 2016).

(2013a) Schweizerische und Europäische Programme für die Nachhaltige Entwicklung der Gemeinden. Available at:

http://www.are.admin.ch/dokumentation/publikationen/00014/00531/index.html?lang=de (accessed 4 August 2016).

__ (2013b) Modellvorhaben Nachhaltige Raumentwicklung - Zusammenarbeit auf grossregionaler Ebene. Available at: http://www.are.admin.ch/themen/raumplanung/modellvorhaben/04079/?lang=de (accessed 4 August 2016).

—_ (2013c) Modellvorhaben Nachhaltige Raumentwicklung - Strategische Teilgebiete der Agglomerationen. Available at:

http://www.are.admin.ch/dokumentation/publikationen/00016/00537/index.html?lang=en (accessed 4 August 2016).

(2013d) Modellvorhaben Nachhaltige Raumentwicklung - Nutzungspotentiale für eine

Siedlungsentwicklung nach innen. Available at:

http://www.are.admin.ch/themen/raumplanung/modellvorhaben/index.html?lang=de (accessed 4 August 2016).

__ (2013e) Neue Wege und Allianzen für die Nachhaltige Raumentwicklung. Available at: https://www.news.admin.ch/message/index.html?lang=de\&msg-id=49985 (accessed 4 August 2016).

—_ (2014a) Agglomerationsprogramme Verkehr und Siedlung. Available at: http://www.are.admin.ch/themen/agglomeration/00626/01680/ (accessed 4 August 2016).

__ (2014b) Bedeutung der Weltweiten Ressourcenverfügbarkeit für die Schweizer

Wettbewerbsfähigkeit. Available at:

http://www.are.admin.ch/dokumentation/publikationen/00014/00563/index.html?lang=de (accessed 4 August 2016).

_ (2015a) Understanding of Sustainability in Switzerland. Available at:

http://www.are.admin.ch/themen/nachhaltig/00260/index.html?lang=en (accessed 4 August 2016).

__ (2015b) Agglomerationsprogramm Stadt Zürich -- Glattal, 2. Generation. Available at: http://www.are.admin.ch/themen/agglomeration/00626/01680/05392/index.html?lang=de (accessed 4 August 2016).

Bundesamt für Statistik (2013) Nachhaltige Entwicklung in Kürze 2013. Available at: $\mathrm{http}: / /$ www.bfs.admin.ch/bfs/portal/de/index/news/publikationen.html?publicationID=5055 (accessed 4 August 2016).

Canton Zurich (2014) Kantonaler Richtplan. Available at: http://www.are.zh.ch/internet/baudirektion/are/de/raumplanung/kantonaler_richtplan.html (accessed 4 August 2016).

Canton Zurich (2015) Daten. Available at: http://www.statistik.zh.ch/internet/justiz_inneres/statistik/de/daten.html (accessed 4 August 2016).

Carr C (2014) Discourse Yes, Implementation Maybe: An Immobility and Paralysis of Sustainable Development Policy. European Planning Studies 22(9): 1824-1840.

Carr C (2015) The power of sustainable development. Regions 300(1): 11-13. 
Carr C (2018) Sustainability in small states: Luxembourg as a post-suburban space under growth pressure in need of a cross-national sustainability. In Brinkmann, R., \& Garren, S. (Eds), The Palgrave Handbook of Sustainability (pp. 727-738). Cham: Palgrave Macmillan.

Carr, C (2019) Introducing Luxembourg: Ephemeral Sustainabilities. In Krueger R, Freytag, T and Mössner, S (eds) Adventures in Sustainable Urbanism. New York: SUNY Press.

Carr, C and Affolderbach, J (2014) Rescaling sustainability? Local opportunities and scalar contradictions. Local Environment - The International Journal of Justice and Sustainability 19(6): 567-571.

Carr C, Becker T, Evrard E, Nienaber B, Roos U, McDonough E, Hesse M, and Krueger R (2015) Raising sustainability/Mobilising sustainability: Why European sustainable urban development initiatives are slow to materialise/Territorial cohesion as a vehicle of sustainability/Sustainable urban development and the challenge of global air transport nodes and spatial integration/Distorted density: Where developers and non-governmental organizations on sustainable urban development agree/Overcoming politics with markets? The co-production of sustainable development in urban and regional planning. Planning Theory and Practice 16(1): 99-125.

Carr, C and Hesse M (2020a) When Alphabet Inc. plans Toronto's Waterfront: New post-political modes of urban governance. Urban Planning 5(1): 69-83.

Carr, C and Hesse M (2020b). Mobility policy through the lens of policy mobility: The post-political case of introducing free transit in Luxembourg. Journal of Transport Geography: 83, 102634

Carr C, Lutz R, Schutz K (2018) There is no one human scale - Reflections on urban development practice in Luxembourg. Urbanization Unbound. Available at: http://158.64.76.181/bitstream/10993/36953/1/There\%20is\%20no\%20one\%20human\%20scale.pdf

Carr C and McDonough E (2014) Whither sustainability? Governance and regional integration in the Glatt Valley. Paper presented at the Regional Studies Association Research Network, "How to govern fundamental Sustainability Transition processes?” 11 July 2014, St. Gallen, Switzerland.

Carr C and McDonough E (2018) Integrative Planning of Post-suburban Growth in the Glatt Valley (Switzerland). Raumforschung und Raumordnung Issue 2/2018

Carr C, McDonough E and Telaar R (2015) Integration als konzeptioneller Baustein und Widerspruch der nachhaltigen Raumplanung, 182: 74-79.

Chen WY (2015) The role of urban green infrastructure in offsetting carbon emissions in 35 major Chinese cites: A nationwide estimate. Cites 44(2015) 112-120.

Davidson M (2010) Sustainability as ideological praxis: the acting out of planning's master-signifier. City 14(4): 390-405.

Davidson M (2012) Sustainable city as fantasy. Human Geography 5(2): 14-25

Desfor G and Keil R (2004) Nature and the City - Making Environmental Policy in Toronto and Los Angeles. Chicago: University of Arizona Press

Diener R, Herzog J, Meili M, de Meuron P and Schmid C (2005). Switzerland: An Urban Portrait. Birkhäuser, Basel.

Elgert L (2016) The double edge of cutting edge: Explaining adoption and nonadoption of the STAR rating system and insights for sustainability indicators. Ecological Indicators, 67, 556-564.

Elgert L (2018) Rating the sustainable city: 'Measurementality', transparency, and unexpected outcomes at the knowledge-policy interface. Environmental Science \& Policy 79, 16-24.

Elgert L and Krueger R (2012) Modernising sustainable development? standardisation, evidence and experts in local indicators. Local Environment 7(5): 561-571.

Evans J and Jones P (2008) Rethinking sustainable urban regeneration: ambiguity, creativity, and the shared territory. Environment and Planning A 40: 1416-1434.

Faludi A (1970) The planning environment and the meaning of 'planning'. Regional Studies 4 1-9.

Federal Statistical Office (FSO) (2008) Sustainable Development Pocket Statistics 2009 Federal Statistics Office, Neuchâtel.

Feindt PH and Oels A (2005) Does discourse matter? Discourse analysis in environmental policy making. Journal of Environmental Policy \& Planning 7(3): 161-173.

Flughafenregion Zürich (2013) Jahresbericht 2013 Flughafenregion, Zurich.

Frantzeskaki N, Wittmayer J and Loorbach D (2014) The role of partnerships in 'realising' urban sustainability in Rotterdam's City Ports Area, The Netherlands. Journal of Cleaner Production 65(2014): 406-417.

Glasze G (2007) The discursive constitution of a world-spanning region and the role of empty signifiers: the case of Francophonia. Geopolitics 12: 656-679. 
Gressgård R (2015) The power of (re) attachment in urban strategy: interrogating the framing of social sustainability in Malmö. Environment and Planning A 47(1): 108-120.

Griggs S and Howarth (2002) An alliance of interest and identity? The campaign against Manchester airport's second runway. Mobilization: An International Journal 7(1): 43-58.

Gunder M (2004) Shaping the planner's ego-ideal: a Lacanian interpretation of planning education. Journal of Planning Education and Research 23(3): 299-311.

Hall PVJ and Stern PR (2014) Implicating waterfronts in regional sustainability. Local Environment: The International Journal of Justice and Sustainability 19(6): 591-604.

Hesse, M., Carr, C. (2013). Integration vs. fragmentation: spatial governance for land and mobility - the case of Luxembourg, in Hesse M., Caruso G., Gerber P. and Viti F. (Eds) Proceedings of the BIVECGIBET Transport Research Days 2013, pp. 379-381.

Hesse, M., Carr, C. (2020). Free Transit in Luxembourg: A case of post-political urban governance through policy mobility. In Witlox, F., (Ed.) Moving Towards More Sustainable Mobility and Transport through Smart Systems-Proceedings of the BIVEC-GIBET Transport Research Days. Ghent: University of Ghent.

Hillier J and Gunder M (2005) Not over your dead bodies! A Lacanian interpretation of urban planning discourse and practice. Environment and Planning A 37: 1049-1066.

Hoelzel F (2014) Eine Frage, zwei Antworten. Hochparterre May 2014, 22-31.

Holden M (2012) Is integrated planning any more than the sum of its parts? Considerations for planning sustainable cities. Journal of Planning Education and Research 32(3): 305-318.

Hooghe L and Marks G. (2001) Multi-Level Governance and European Integration. Rowman \& Littlefield, Oxford.

Hooghe L and Marks G (2003) Unraveling the Central State, but How? Types of Multi-level Governance. American Political Science Review 97(2): 233-243.

Hudson R (2017) Facing forwards, looking backwards: Coming to terms with continuing uneven development in Europe. European Urban and Regional Studies 24(2) 138-141.

Jorgensen M and Phillips LJ (2002) Discourse Analysis as Theory and Method. Sage, London.

Kanton Zürich (2015) Kantonaler Richtplan. Available at: http://www.are.zh.ch/internet/baudirektion/are/de/raumplanung/kantonaler_richtplan.html (accessed 4 August 2016).

Koll-Schretzenmayr M and Schmid WA (2003) Agglomerationspolitik in der Schweiz: Einsichten und Ausblicke am Beispiel der 'Glattal-Stadt'. disP - The Planning Review 39(152): 4-14.

Krueger R and Gibbs D (2007) The Sustainable Development Paradox: Urban Political Economy in the United States and Europe. New York: The Guilford Press.

Krueger R, Gibbs D and Carr C (2018) Examining Regional Competitiveness and the Pressures of Rapid Growth: An interpretive institutionalist account of policy responses in three city regions. Environment and Planning C: Politics and Space. doi.org/10.1177/2399654418767661

Landschaftsinitiative (2015a) Möglichkeiten einer haushälterischen Nutzung des Bodens durch Begrenzung der Bauzonengrösse und bessere Steuerung der Lage von Bauzonenreserven. Available at: http://www.landschaftsinitiative.ch/tl_files/PDF_Dateien/PDF_D/091208_Bericht\%20Bauzonen.pdf (accessed 4 August 2016).

Landschaftsinitiative (2015b) Was die Landschaftsinitiative will. Available at: http://www.landschaftsinitiative.ch/tl_files/PDF_Dateien/PDF_D/0802_was_will_init_2.pdf (accessed 4 August 2016).

Landschaftsinitiative (2015c) Beispiele positiver Siedlungsentwicklung. Available at: http://www.landschaftsinitiative.ch/tl_files/PDF_Dateien/PDF_D/0802_pos_bsp_4.pdf (accessed 4 August 2016).

Lobsiger-Kägi, E., Renner, E., Kunz, M. and Fricker, J. (2014) Soziale Aspekte Der Nachhaltigen Entwicklung - Grundlagen Für Die Nachhaltigkeitsbeurteilung von Projekten. Bundesamt für Raumentwicklung, Bern.

Moore S and Bunce S (2009) "Delivering sustainable buildings and communities: eclipsing social concerns through private sector-led urban regeneration and development" Local Environment: The Journal of Justice and Sustainability, 14(7): 601-606.

Mössner S (2016) Sustainable urban development as consensual practice: post-politics in Freiburg, Germany. Regional Studies 50(6): 971-982. 
Raco M (2005) Sustainable Development, Rolled-out Neoliberalism and Sustainable Communities. Antipode - A Radical Journal of Geography 37(2): 324-347.

Rérat P and Lees L (2011) Spatial capital, gentrification and mobility: evidence from Swiss core cities. Transactions of the Institute of British Geographers 36(1): 126-142.

Rérat P (2012) Housing, the compact city and sustainable development: Some insights from recent urban trends in Switzerland. International Journal of Housing Policy 12(2): 115-136.

Richard C, Wachter D and Bundesamt für Raumentwicklung (ARE) (2012) Sustainable Development in Switzerland - A Guide. Available at: http://www.are.admin.ch/themen/nachhaltig/00260/index.html?lang=en (accessed 4 August 2016).

Rydin Y (2010) Governing for Sustainable Urban Development. New York: Earthscan.

Saussure F (1959) Course in General Linguistics. New York: The Philosophical Library.

Schweizirscher Bundesrat (2008) Strategie nachhaltige Entwicklung - Leitlinien und Aktionsplan 20082011. Available at: http://www.are.admin.ch/themen/nachhaltig/00262/00528/index.html?lang=de (accessed 5 January 2015).

(2012) Strategie Nachhaltige Entwicklung 2012-2015. Available at:

http://www.are.admin.ch/themen/nachhaltig/00262/00528/index.html?lang=de (accessed 5 January 2015).

- (2014) Botschaft zum Bundesbeschluss über die Freigabe der Mittel ab 2015 für das Programm Agglomerationsverkehr. Available at: https:/www.admin.ch/opc/de/federal-gazette/2014/2511.pdf (accessed 4 August 2016).

Schweizischer Bundesrat, KdK, BPUK, SSV, SGV (2012) Raumkonzept Schweiz. Available at: http://www.are.admin.ch/themen/raumplanung/00228/00274/ (accessed 4 August 2016).

Shaker RR (2015) The spatial distribution of development in Europe and its underlying sustainability correlations. Applied Geography 63(2015) 304-314.

Swiss Federal Council (2015) Bundesgesetz über die Raumplanung. Available at: https://www.admin.ch/opc/de/classified-compilation/19790171/index.html. (accessed 4 August 2016).

Swyngedouw E (2007) Impossible 'Sustainability' and the Postpolitical Conditiom. In R. Krueger and D. Gibbs (eds.) The Sustainable Development Paradox: Urban Political Economy in the United States and Europe Eds. New York: The Guilford Press. pp 13- 40.

Verein Metropolitanraum Zürich (2014) Metropolitanraum als Parklandschaft, Siedlungsnahes Freiraumnetz. Available at: http:// http://www.metropolitanraum-zuerich.ch/epaper/index.html\#/2 (accessed 4 August 2016).

While A, Jonas AEG and Gibbs D (2004) The Environment and the Entrepreneurial City: Searching for the Urban 'Sustainability Fix' in Manchester and Leeds. International Journal of Urban and Regional Research 283: 549-569. 